Check for updates

The BMJ

Cite this as: BMJ 2021;374:n1876 http://dx.doi.org/10.1136/bmi.n1876 Published: 25 July 2021

\title{
Covid-19: Lessons from UK's pandemic response "cannot wait” for government inquiry, say MPs
}

\section{Gareth lacobucci}

The lifetime cost of the UK government's response to the covid-19 pandemic reached $€ 372$ bn by May 2021 and will expose the taxpayer to "significant financial risks for decades to come," a parliamentary committee has warned.

In two hard hitting reports the House of Commons Public Accounts Committee pinpointed an "unacceptably high" waste in areas such as the procurement of personal protective equipment, a "repeated failure to provide a full rationale for key decisions," and poor communication of government guidelines as key initial lessons from the UK's pandemic response. ${ }^{12}$

Although the government has promised to begin a public inquiry into its handling of the pandemic in spring 2022, the committee said this could take years to complete. "We are clear that the government cannot wait for the review before learning important lessons," it said.

\section{PPE waste}

The committee said it remained "seriously concerned" that despite spending £1obn on PPE supplies, the stockpile "is not fit for purpose." Of 32 billion items of PPE ordered by the Department of Health and Social Care (as at May 2021), 11 billion had been distributed, 12.6 billion were stored in the UK as central stock, and 8.4 billion on order from other parts of the world had still not arrived in the UK, the committee said.

It estimated that the current PPE stockpile was costing the health department around $£ 6.7 \mathrm{~m}$ a week to store. "Potential waste levels are unacceptably high, with 2.1 billion items of PPE unsuitable for being used in medical settings, equating to over Ł2bn of taxpayers' money," it warned.

The MPs also concluded that the government had yet to create any robust plans for repurposing and distributing excess PPE that is suitable for medical use in a way that ensured value for money and protected staff and patients.

\section{Other key lessons}

The government's "repeated failure to provide a full rationale for key decisions" was another lesson, with MPs saying that it had undermined its accountability for the pandemic response and the public's trust.

Of 1644 contracts with a value more than $£ 25000$ awarded up to the end of July 2020, $75 \%$ were not published within the 90 day target. Achieving value for money from government spending during the pandemic had been compromised by poor quality impact assessments and assessments by accounting officers, the MPs added.
The committee also identified the "constant pressure" that healthcare staff have been under during the pandemic, urging the government to provide more mental health and emotional support for them, and a "substantive long term NHS workforce plan" to ensure the workforce's future resilience.

Poor government communication during the pandemic was also highlighted. "A lack of clarity [and] timeliness and the volume of government communications has, at times, hindered the public's understanding of guidelines and ability to comply with them," it said.

The committee urged the government to "set out a fully costed plan for recovering from the pandemic" in its autumn spending review, alongside a comprehensive framework for managing the risks to public finances resulting from the UK's pandemic response.

The committee's chair, Meg Hillier, said, "With eyewatering sums of money spent on covid measures so far, the government needs to be clear, now, how this will be managed going forward and over what period of time.

"If coronavirus is with us for a long time, the financial hangover could leave future generations with a big headache."

1 House of Commons Public Accounts Committee. PAC report HC-173: Covid19 cost-tracker conclusions and recommendations. 25 Jul 2021. https://committees.parliament.uk/work/1224/covid19-cost-tracker-update.

2 House of Commons Public Accounts Committee. PAC report HC-175: Initial lessons from the government response to covid 19: conclusions and recommendations. 25 Jul 2021. https://committees. parliament.uk/work/1225/initial-lessons-from-the-governments-response-to-thecovid19-pandemic.

This article is made freely available for use in accordance with BMJ's website terms and conditions for the duration of the covid-19 pandemic or until otherwise determined by BMJ. You may use, download and print the article for any lawful, non-commercial purpose (including text and data mining) provided that all copyright notices and trade marks are retained. 